\title{
PENGARUH SENAM KAKI TERHADAP NILAI ANKLE BRACHIAL INDEX (ABI) PADA PASIEN DM TIPE II DI PERSADIA UNIT DR. MOEWARDI TAHUN 2015
}

\author{
Agus Trianto, Rini Tri Hastuti \\ Kementerian Kesehatan Politeknik Kesehatan Surakarta Jurusan Keperawatan
}

\begin{abstract}
Kind II of DM, Foot Excercise, Ankle Brachial Index (ABI) Value. Many Patients that go through complications of Type II DM. One of the complication is foot diabetik, its needed implementation to prevent of the complication. The implementation that be doing is exercise. Exercise that be doing is foot exercise that have function to increase the peripheral blood circulation. The Objective of the research is to know the effect of foot exercise to Ankle Brachial Index (ABI) value of the type II of DM patient in unit of Persadia Dr. Moewardi hospital year 2015.Kind of the research is quasy experimental research. Design of the research is one group pretest post test design. The researcher conducted measurement value Ankle brachial index (ABI) before doing foot exercise and measurement Ankle Brachial Index (ABI) value after foot exercise. The analysis by using pairet test $t$-test. Result of the research from paired t-test, the effect of foot exercise showed findings Sig value. (2-tailed) is 0,001 or ABI value $p<0.05$, with average change ABI value before and after is equal to 0.05211, So from the test result of paired t-test it can be meant that Ho is rejected and Ha be accepted. That have meaning there are effect of foot exercise to ABI value.
\end{abstract}

\section{Keywords : Kind II of DM, Foot Excercise, Ankle Brachial Index (ABI) Value}

Abstrak : Diabetes Mellitus Tipe II, Senam Kaki, Nilai Ankle Brachial Index (ABI). Banyak pasien yang mengalami komplikasi DM Tipe II. Salah satu komplikasinya adalah kaki diabetes, perlu dilakukan penatalaksanaan untuk mencegah komplikasi tersebut. Penatalaksanaan yang dilakukan adalah latihan fisik. Latian fisik dapat berupa senam kaki diabetes yang berfungsi untuk meningkatkan sirkulasi darah perifer.Tujuan penelitian ini adalah mengetahui pengaruh senam kaki terhadap nilai Ankle Brachial Index $(A B I)$ pada pasien DM tipe II di Persadia Unit Dr. Moewardi tahun 2015. Jenis penelitian ini adalah penelitian Quasy eksperiment. Desain Penelitian ini adalah one group pretest post test design, peneliti melakukan pengukuran Nilai Ankle brachial Index ( $A B I)$ sebelum dilakukan senam kaki dan pengukuran Nilai Ankle Brachial Index ( $A B I$ ) sesudah dilakukan senam kaki. Analisis yang digunakan adalah uji Pairet t-test. Hasil penelitian ini didapatkan uji paired t-test pengaruh senam kaki menunjukkan hasil nilai Sig.(2-tailed) nilai ABI yaitu 0,001 atau <0,05, dengan perubahan rata-rata nilai ABI sebelum dengan sesudah yaitu sebesar 0,05211 maka dari hasil uji paired t-test dapat diartikan bahwa Ho ditolak dan Ha diterima yang artinya ada pengaruh senam kaki terhadap nilai ABI.

\section{Kata Kunci : Diabetes Mellitus Tipe II, Senam Kaki, Nilai Ankle Brachial Index (ABI)}




\section{PENDAHULUAN}

Peningkatan pendapatan perkapita dan peningkatan perubahan gaya hidup terutama di kota-kota besar, menyebabkan peningkatan prevalensi penyakit degeneratif, salah satunya adalah penyakit Diabetes Mellitus. Diabetes Mellitus (DM) merupakan salah satu penyakit yang berdampak pada produktivitas dan dapat menurunkan sumber daya manusia, penyakit ini tidak hanya berpengaruh pada satu individu, tetapi sistem kesehatan suatu Negara. Meningkatnya prevalensi DM di beberapa negara berkembang akibat peningkatan kemakmuran di berbagai negara yang bersangkutan dan akhir-akhir ini banyak disoroti (Suyono, 2009).

Penyebab penyakit DM Tipe II yang sering dijumpai terjadinya diabetes melitus diantaranya kurang olah raga dan kebiasaan makan banyak kalori, riwayat diabetes dalam keluarga, usia, riwayat diabetes gestasional terdahulu (Nabyl, 2009), selain itu Riyadi (2008) mengatakan gaya hidup stres, pola makan yang salah, dan adanya infeksi dapat menjadi faktor penyebab timbulnya DM Tipe II. Berbagai faktor penyebab tersebut dapat mengakibatkan berbagai komplikasi. Menurut Misnadiarly (2006) mengatakan komplikasi menahun yang dapat terjadi pada diabetes melitus adalah terjadinya penurunan kemampuan seksualitas, tejadinya neuropati simtomatik, retino diabetik, katarak, TBC, Hipertensi, gangren diabetik dan batu empedu simtomatik, untuk pencegahan maupun penanganan DM Tipe II perlu dilakukan penatalaksanaan DM Tipe II.

Penatalaksanaan untuk mencegah terjadinya komplikasi tersebut dapat dilakukan terapi diabetes. Penatalaksanaan diabetes terdiri dari lima komponen yaitu diet, latihan jasmani, pemantauan kadar glukosa, terapi dan pendidikan. Komponen latihan jasmani atau olah raga sangat penting dalam penatalaksanaan diabetes karena efeknya dapat menurunkan kadar glukosa darah dengan meningkatkan pengambilan glukosa oleh otot dan memperbaiki pemakaian insulin (Smeltzer \& Bare, 2002). Didukung oleh Soewondo (2005) mengatakan latihan fisik pada penderita DM memiliki peranan yang sangat penting dalam mengendalikan kadar gula dalam darah, dimana saat melakukan latihan fisik terjadi peningkatan pemakaian glukosa oleh otot yang aktif sehingga secara langsung dapat menyebabkan penurunan glukosa darah. Latihan fisik juga dapat mengubah kadar lemak darah yaitu meningkatkan kadar HDL-kolesterol dan menurunkan kadar kolesterol total serta trigliserida (Smeltzer \& Bare, 2002). Selain itu, melakukan olahraga yang teratur dapat menurunkan tekanan darah dikarenakan latihan fisik yang teratur dapat melebarkan pembuluh darah (Misnadiarly, 2006). Contoh latihan jasmani atau Latihan Fisik yang dianjurkan salah satunya adalah senam kaki diabetes. Senam kaki dapat membantu memperbaiki sirkulasi darah dan memperkuat otot-otot kecil kaki dan mencegah terjadinya kelainan bentuk kaki (Deformitas), dan mengatasi keterbatasan gerak sendi. Senam kaki diabetes melitus dapat dilakukan dengan posisi berdiri, duduk dan tidur dengan menggerakan kaki dan sendi misalnya dengan kedua tumit diangkat, mengangkat kaki dan menurunkan kaki (Soegondo et al, 2007). Gerakan dalam senam kaki DM tersebut seperti yang disampaikan dalam $3 r d$ National Diabetes Educators Training Camp tahun 2005 dapat membantu 
memperbaiki sirkulasi darah di kaki (Soewondo, 2005).

Penilaian keefektifan sirkulasi pembuluh darah dapat dideteksi dengan pengukuran nilai ankle brachial index (ABI), dengan menghitung rasio tekanan darah sistolik pembuluh darah arteri pergelangan kaki dibandingkan pembuluh darah arteri lengan. Ankle brachial index dapat juga mendeteksi lesi stenosis paling sedikit $50 \%$ pada tungkai dan sangat bermanfaat untuk mendeteksi awal adanya gangguan sirkulasi darah pada kaki yang dapat menimbulkan kaki diabetic (Misnadiarly, 2006).

Anggota komunitas Persadia Unit RSUD Dr.Moewardi yang aktif mengikuti kegiatan Persadia setiap minggunya berjumlah 50 orang, dengan 30 orang diantaranya pasien Penderita DM Tipe II (Persadia Unit RSUD Dr. Moewardi Surakarta, 2014)

\section{METODE PENELITIAN}

Penelitian ini merupakan penelitian quasy ekperimetal dengan one group pretest post test design. Penelitian ini bertujuan untuk mengetahui pengaruh senam kaki terhadap nilai Ankle Brachial Index $(A B I)$. Penelitian quasy eksperimental adalah suatu bentuk Penelitian yang dilakukan untuk mengetahui akibat yang ditimbulkan dari suatu perlakuan yang diberikan secara sengaja oleh peneliti yang bertujuan untuk menilai pengaruh suatu tindakan atau perlakuan (Wasis, 2008). Desain Penelitian ini adalah one group pretest post test design, peneliti melakukan pengukuran Nilai Ankle brachial Index (ABI) sebelum dilakukan senam kaki dan pengukuran Nilai Ankle Brachial Index $(A B I)$ sesudah dilakukan senam kaki.
Dengan jumlah responden sebanyak 19 responden.

Analisa univariat disajikan distribusi frekuensi karakteristik responden (Umur dan Jenis kelamin) dalam bentuk presentasi dan nilai ankle brachial index sebelum dan sesudah senam dalam bentuk sentral tendensi yang terdiri dari mean, median, modus, sudut deviasi, standar minimum dan maximum sehingga akan tergambar fenomena yang berhubungan dengan variabel yang diteliti. Analisa univariat bertujuan untuk mengetahui nilai Ankle Brachial Index (ABI) pada pasien DM tipe II sebelum dan sesudah dilakukan senam kaki.

Analisis Bivariat dilakukan untuk mengetahui bagaimana pengaruh senam kaki terhadap nilai Ankle Brachial Index (ABI) pasien DM Tipe II. Pada analisa bivariat ini peneliti akan melakukan uji normalitas data menggunakan Shapirowilk. Data berdistribusi normal menggunakan uji statistik parametric. Pengujian hipotesis parametrik yang digunakan adalah dengan uji paired sample t-test, karena dilihat dari skala data yang digunakan termasuk numerik dan sampel yang digunakan adalah sampel berpasangan.

\section{HASIL PENELITIAN}

Berdasarkan

Karakteristik responden sebaran jenis kelamin responden dicermati pada tabel 1

Tabel 1

Distribusi Frekuensi Berdasarkan Jenis Kelamin

\begin{tabular}{lccc}
\hline No & Jenis kelamin & Jumlah $(\mathrm{n})$ & Prosentase $(\%)$ \\
\hline 1. & Laki-laki & 6 & 31,6 \\
2. & Perempuan & 13 & 68,4 \\
\hline & Total & 19 & 100 \\
\hline & Hasil & Penelitian & menunjukkan
\end{tabular}

bahwa responden paling banyak adalah 
perempuan sejumlah 13 responden atau $68,4 \%$, sedangkan laki-laki sejumlah 6 responden atau $31,6 \%$.

Sebaran umur responden dicermati pada tabel 2

Tabel 2

Distribusi Frekuensi Berdasarkan Umur

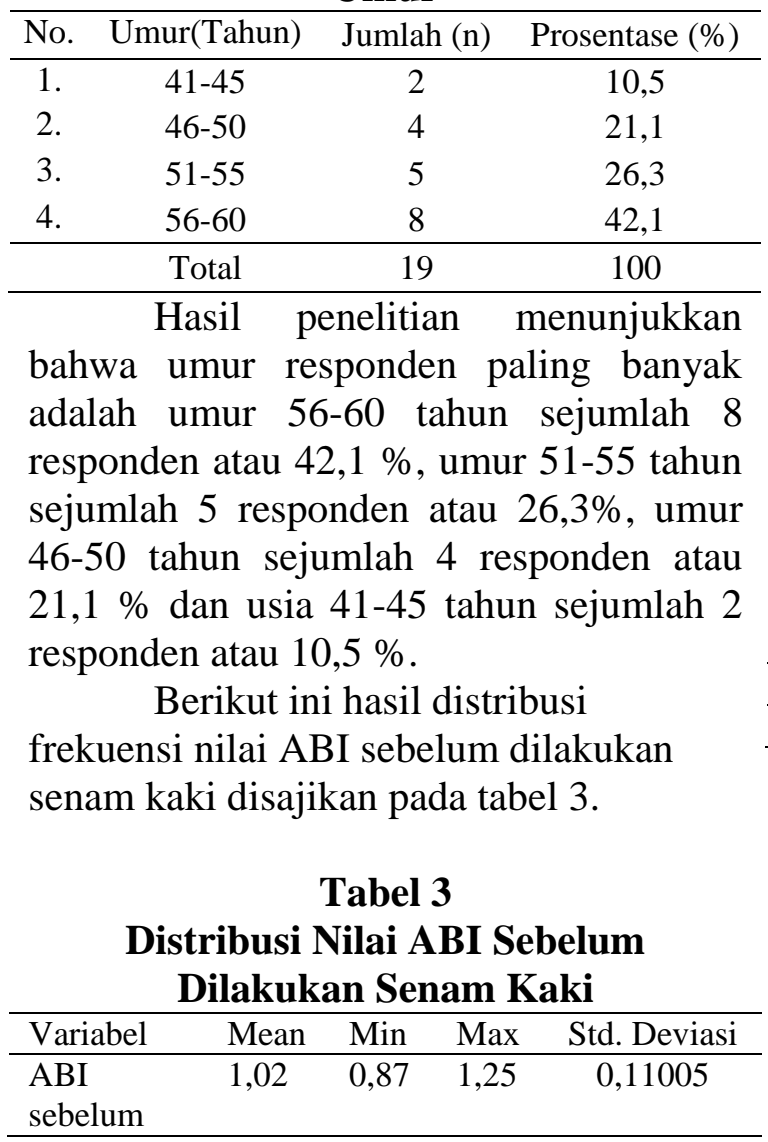

Berdasarkan tabel 3 diketahui bahwa dari hasil nilai ABI sebelum dilakukan senam kaki yang terdiri dari 19 responden memiliki nilai mean sebesar 1,02 , nilai minimal 0,87 dan nilai maksimal 1,25.

Berikut ini hasil distribusi frekuensi nilai $A B I$ sesudah dilakukan senam kaki disajikan pada tabel 4 .
Tabel 4

Distribusi Nilai ABI Sesudah Dilakukan Senam Kaki

\begin{tabular}{|c|c|c|c|c|}
\hline Variabel & Mean & Min & Max & Std. Deviasi \\
\hline $\begin{array}{l}\text { ABI } \\
\text { sesudah }\end{array}$ & 1,07 & 0,86 & 1,30 & 0,12168 \\
\hline
\end{tabular}
bahwa dari hasil nilai ABI sesudah dilakukan senam kaki yang terdiri dari 19 responden memiliki nilai mean sebesar 1,07, nilai minimal 0,86 dan nilai maksimal 1,30.

Analisis data melalui uji paired $t$ test dilakukan dengan bantuan computer program SPSS versi 19.0 for windows. Syarat data bersifat signifikan apabila nilai $\mathrm{p}$ lebih kecil dari taraf signifikansi 5 $\%$. Hasil perhitungan paired t-test disajikan pada tabel 4.5 .

\section{Tabel 5}

\section{Perubahan Nilai ABI Sebelum dan Sesudah Dilakukan Senam Kaki}

\begin{tabular}{llll}
\hline Variabel & Mean & $\mathrm{t}$ & Sig.(2tailed) \\
\hline ABI & 0,05211 & 4,061 & 0,001 \\
\hline & Hasi &
\end{tabular}

Hasil uji paired t-test pengaruh senam kaki menunjukkan hasil nilai Sig.(2-tailed) nilai ABI yaitu 0,001 atau < 0,05 , dengan perubahan rata-rata nilai ABI sebelum dengan sesudah yaitu sebesar 0,05211 maka dari hasil uji paired t-test dapat diartikan bahwa Ho ditolak dan $\mathrm{Ha}$ diterima yang artinya ada pengaruh senam kaki terhadap nilai ABI.

\section{PEMBAHASAN}

Hasil analisis menunjukkan jumlah responden laki-laki sebanyak 6 responden $(31,6 \%)$ dan responden wanita sebanyak 13 responden $(68,4 \%)$. Jumlah responden perempuan dapat dilihat jumlahnya lebih banyak dibandingkan responden laki-laki. Perempuan memiliki resiko lebih besar untuk menderita Diabetes Mellitus, berhubungan dengan paritas dan 
kehamilan, dimana keduanya adalah faktor resiko untuk terjadinya penyakit DM. Dalam penelitian Martono dengan desain cross sectional di Jawa Barat tahun 2001 ditemukan bahwa penderita DM lebih banyak pada perempuan (63\%) dibandingkan laki-laki (37\%). Demikian pula pada penelitian Media tahun 2003 di seluruh rumah sakit di Kota Bogor, proporsi pasien DM lebih tinggi pada perempuan $(61,8 \%)$ dibandingkan pasien laki-laki $(38,2 \%)$. Hasil penelitian ini juga sesuai dengan teori yang dikemukakan Smeltzer \& Bare (2002) yang menyebutkan wanita lebih banyak menderita DM daripada pria.

Hasil penelitian didapatkan bahwa umur 56-60 tahun lebih banyak yaitu 8 responden atau $57,5 \%$. Hal ini sesuai yang dikemukakan Smeltzer \& Bare (2001) yang memaparkan bahwa usia > 45 tahun fungsi organ tubuh semakin menurun, hal ini diakibatkan aktivitas sel beta pankreas untuk menghasilkan insulin menjadi berkurang. DM pada usia lanjut cenderung meningkat, hal ini dikarenakan DM pada usia lanjut bersifat multifactorial yang dipengarui factor ekstrinsik dan instrinsik. Umur merupakan salah satu factor yang bersifat mandiri dalam pengaruhnya terhadap perubahan toleransi tubuh terhadap glukosa.Umumnya pasien diabetes pada usia lanjut $90 \%$ termasuk diabetes tipe II dan berusia $>45$ tahun (Gustiyani, 2006).

Nilai ABI pada pasien DM Tipe II lebih kecil dibandingkan non-DM. Pada pasien yang tidak memiliki gangguan peredaran darah pada kaki akan memiliki nilai $A B I$ 0,9-1,3 dan dikatakan memiliki gangguan peredaran darah kaki bila nilai $\mathrm{ABI}<0,9$.

Setelah dilakukan senam kaki menunjukkan adanya peningkatan sirkulasi darah atau nilai ABI menunjukkan peningkatan, dengan rentang ABI 0,9-1,3 ( rentang normal) dan $<0,9$ (rentang abnormal).

Hasil penelitian menunjukkan uji paired t-test pengaruh senam kaki menunjukkan hasil nilai Sig.(2-tailed) nilai ABI yaitu 0,001 atau $p<0,05$, dengan perubahan rata-rata nilai $\mathrm{ABI}$ sebelum dengan sesudah yaitu sebesar 0,05211 maka dari hasil uji paired t-test dapat diartikan bahwa Ho ditolak dan $\mathrm{Ha}$ diterima yang artinya ada pengaruh senam kaki terhadap nilai ABI.

Ada pengaruh senam kaki diabetes terhadap nilai ankle brachial index (ABI) . Senam kaki diabetes dapat meningkatkan nilai ankle brachial index (ABI) hal itu terjadi karena senam kaki membantu memperbaiki sirkulasi darah dan memperkuat otot-otot kecil kaki dan mencegah terjadinya kelainan bentuk kaki (Deformitas), dan mengatasi keterbatasan gerak sendi.

\section{KESIMPULAN DAN SARAN}

Deskripsi karakteristik responden, menurut jenis kelamin didominasi oleh responden berjenis kelamin perempuan sebanyak 13 responden $(68,4 \%)$. Sedangkan menurut umur, banyak terjadi pada rentang umur 56-60 tahun yaitu sebanyak 8 responden $(42,1 \%)$.

Nilai ABI sebelum dilakukan senam kaki sebanyak 19 responden didapatkan hasil nilai tertinggi 1,25 dan nilai terendah 0,87 . Rata-rata nilai $\mathrm{ABI}$ sebelum dilakukan senam kaki adalah 1,0200.Nilai ABI sesudah dilakukan senam kaki sebanyak 19 responden didapatkan hasil nilai tertinggi 1,30 dan nilai terendah 0,86. Rata-rata nilai $\mathrm{ABI}$ sesudah dilakukan senam kaki adalah 1,0721 . 
Ada pengaruh senam kaki terhadap nilai ankle bracial index (ABI) pada pasien DM tipe II di persadia unit RSUD Dr. Moewardi Surakarta. Hasil signifikasi (p) nilai ABI yaitu 0,001 atau $\mathrm{p}<0,05$, dengan perubahan rata-rata nilai $\mathrm{ABI}$ sebelum dengan sesudah yaitu sebesar 0 , 05211 ,dapat diartikan bahwa Ho ditolak dan Ha diterima

Saran yang diberikan bagi penelitian selanjutnya diharapkan dapat mengembangkan penelitian yang lebih luas, baik variable, jumlah sampelnya,maupun waktu dan tempat penelitian.

Bagi komunitas Persadia diharapkan untuk dapat meningkatkan pengetahuan tentang pengendalian DM dengan latihan fisik khususnya Senam Kaki dalam meningkatkan sirkulasi darah pada area perifer yang di ukur dengan ABI.

Bagi Perawat diharapkan dapat menjadikan penelitian ini sebagai bahan wacana untuk meningkatkan wawasan dan pengetahuan perawat dalam mengelola pasien DM Tipe II.

Bagi perkembangan ilmu pengetahuan, diharapkan dapat menjadikan penelitian ini sebagai wacana keilmuan terutama dalam pemberian tindakan keperawatan pada pasien DM Tipe II.

Bagi institusi pendidikan diharapkan dapat membekali mahasiswanya tentang pelaksanaan senam kaki dan cara pengukuran $\mathrm{ABI}$ yang dapat digunakan sebagai salah satu indicator pengkajian keperawatan endokrin untuk mahasiswa yang akan melakukan praktek klinik.

\section{DAFTAR RUJUKAN}

Martono. Hadianto. (2001). Gambaran Pasien DM Tipe II di RSUD Bogor Tahun 2001. Thesis Universitas Padjajaran: tidak diterbitkan Medical Record (2014) Persadia Unit RSUD dr. Moewardi Surakarta.

Misnadiarly. (2006). Diabetes mellitus gangrene, ulcer, infeksi, mengenali gejala, menaggulangi dan mencegah komplikasi. Jakarta : OborPopuler.

Nabyl. (2009). Mengenal Diabetes Mellitus. Jakarta: Gramedia Pustaka Utama.

Nursalam. (2008). Proses dan Dokumentasi Keperawatan :Konsep dan Praktik. Jakarta: Salemba Medika.

Riyadi, Sujono. (2008). Asuhan Keperawatan Medical Bedah. Edisi 1. Yogyakarta : Graha Ilmu.

Sekretariat Persadia Unit RSUD Dr. Moewardi. (2014). Daftar Anggota Persadia Unit RSUD Dr. Moewardi. Surakart :Persadia Unit RSUD Dr. Moewardi

Smeltzer Suzane C, Bare Brenda. (2002). Buku Ajar Keperawatan Medical Bedah. ,Volume 2, Edisi 8, Alih Bahasa dr. Andri Hartono et al Jakarta: EGC.

Soegondo. (2005). Diagnosis dan klasifikasi Diabetes terkini. Jakarta: FKUI.

Soetedjo. (2009). Buku Saku Mengenal Penyakit Melalui Hasil Pemeriksaan Laboratorium. Yogyakarta: Amara Books.

Soewondo. (2005). Diagnosis dan klasifikasi Diabetes terkini . dalam Soegondo S (dkk). 
Penatalaksanaan DM Terpadu. Jakarta: Amara FKUI.

Suyono, S. (2009). Diabetus mellitus di Indonesi. Jakarta : Pusat Penerbit IPD FK UI .

Wasis. (2008). Pedoman Riset Praktik Profesi Perawat. Jakarta: EGC.

Waspadji S. (2002). Kegawatan pada diabetes melitus, dalam: Petunjuk Praktis Pengelolaan Diabetes Melitus. Jakarta: PB PERKENI. 